\title{
Optimizing Different Conditions to Develop a Single Stranded Phage-Lambda DNA (ADNA) Tightrope
}

\author{
Gali Adamu Ishaku ${ }^{1,2}$ \\ ${ }^{1}$ School of Biological Sciences, University of Essex, Essex, United Kingdom \\ ${ }^{2}$ Department of Biotechnology, Modibbo Adama University of Technology, Yola, Adamawa, Nigeria
}

Email address:

igali@mautch.edu.ng

To cite this article:

Gali Adamu Ishaku. Optimizing Different Conditions to Develop a Single Stranded Phage-Lambda DNA ( $\lambda$ DNA) Tightrope. International Journal of Biomedical Science and Engineering. Vol. 7, No. 3, 2019, pp. 61-67. doi: 10.11648/j.ijbse.20190703.11

Received: August 14, 2019; Accepted: September 9, 2019; Published: September 24, 2019

\begin{abstract}
DNA tightrope can be referred to as $\lambda$ DNA is suspended between two beads above the surface of the flow cell which allows the $\lambda$ DNA to be viewed extended rather than in collapse form. It is use for DNA studies such DNA repairs, but when using the normal protocol (at a velocity of $300 \mu \mathrm{l} /$ minutes, beads size of $5 \mu \mathrm{m}$ and concentration of $500.0 \mu \mathrm{g} / \mathrm{ml} \mathrm{of} 1.0$ $\lambda \mathrm{DNA})$ it results to multiple tightropes forming on the beads which interference with a many studies. In this study, different conditions were optimized to develop a single stranded $\lambda$ DNA tight rope by taking into consideration the following conditions, velocity (100 to 600$)$, beads size $(3 \mu \mathrm{m}$ and $5 \mu \mathrm{m})$, concentration $(500.0 \mu \mathrm{g} / \mathrm{ml}, 375.0 \mu \mathrm{g} / \mathrm{ml}$ and $250.0 \mu \mathrm{g} / \mathrm{ml})$ and time. To form the tightrope, beads were added into water in an eppendorf tube, centrifuged and sonicated before putting into the flow cell. The flow cell, syringe pump and perfusion tube were all fixed together, where ABC buffer and $\lambda$ DNA were put into the perfusion tube and set according to protocol to make the tightropes. YOYO-1 dye was used to stain the $\lambda$ DNA before using atomic force microscopy to image the tightropes, the same procedure was repeated for the different conditions and all dispense readings of the flow rate were taken at not less than $3.0 \mu \mathrm{l} /$ minutes. $\lambda$ DNA on the surface of the flow cell was observed at the velocity of 100 and $200 \mu \mathrm{l} /$ minutes for all the conditions. The optimized result was at velocity of $300 \mu 1 / \mathrm{ml}$, concentration $375.0 \mu \mathrm{g} / \mathrm{ml}$ of $1.0 \mu \lambda \mathrm{DNA}$ and beads size of $3 \mu \mathrm{l}$ which lasted for 15 minutes which gave the best result of single stranded $\lambda \mathrm{DNA}$ tightrope compared to all the conditions and the normal protocol.
\end{abstract}

Keywords: Beads, DNA Tightrope, Flow Cell, Phage-Lambda ( $\lambda$ DNA) and Yoyo-1 Dye

\section{Introduction}

Phage-Lambda DNA ( $\lambda$ DNA) tightrope can be referred to as when $\lambda$ DNA is suspended between two beads above the surface of flow cell which allows the $\lambda$ DNA to be viewed extended rather than in collapse form [1]. DNA tightrope is very useful in Single molecular technique studies because of the advantages it has over other methods which include, the adjacent tightrope which are visible creates a linear network of DNA akin which allow the simultaneous observation of multiple DNA and protein interactions. Another importance of tightrope is that it prevents interaction between DNA or protein and the surface of the flow cell. In addition since the tightropes are suspended between beads, it allows the observation of many modes of protein interactions on the tightrope such as jumping of DNA or protein from one molecule to another and sliding [2-3].

The most effective and convincing way to decipher DNA and protein interaction is to observe direct protein binding under well-controlled condition, to actualized this scientist have developed very powerful methods and instruments like Total Internal Reflection Fluorescence Microscopy (TIRFM) and Atomic Force Microscopy (AFM) [3-5]. One of these well-controlled conditions is through the use of DNA tightrope assay and instrument [1, 6-7]. Such single molecular technique has been in rapid progression for the past twenty years $[3,8-11]$ and has revolutionized the way to study DNA-protein and DNA-ligand interaction in addition to other biological processes [12-13]. This technique also elucidates how the DNA binding protein locates their target sites on the damaged DNA [15-17]. One of method used for this type of study is by $\lambda$ DNA tightrope which is stained with YOYO-1 dye to aid imaging and where protein can also be 
seen in real time $[1,4,18-19]$.

Optimization studies have been performed to enhance real time imaging of protein-DNA interactions following the single molecule technique which includes DNA-binding protein platforms. This approach was initiated over two decades ago when Kabata and colleagues applied dielectrophoresis to extend $\lambda$ DNA [20]. The common feature of this approach for the direct visualization of single molecule DNA-binding protein is the binding and extension of DNA. DNA binding to a specific end on the surface is required for visualization. However, due to the elastic nature of DNA, the binding (tethering) on its own cannot adequately extend a DNA molecule for use in single-molecule imaging using high resolution equipment [1]. Studies reveal that the applications of shear force produced by hydrodynamic flow have been successful in stretching DNA adequately [21-23].

This DNA tightrope when formed, results in multiple strands of DNA forming on beads or multiple tightropes and these multiple tightropes usually clumps together which then interfere with the activities of DNA or protein during experimental studies. In this study, we optimized the different conditions such as, $5 \mu \mathrm{M}$ and $3 \mu \mathrm{M}$ bead sizes, Concentrations of $500.0 \mu \mathrm{g} / \mathrm{ml}, 375.0 \mu \mathrm{g} / \mathrm{ml}$ and $250.0 \mu \mathrm{g} / \mathrm{ml}$ and Velocity of the syringe pump 100, 200, 300, 400 and 500. Where optimized result was compared to the normal protocolof forming $\lambda$ DNA (beads size of $5 \mu \mathrm{M}$, velocity of $300 \mu \mathrm{l} / \mathrm{Mins}$. concentration of $500.0 \mu \mathrm{g} / \mathrm{ml}$ at not less than 20 mins).

\section{Materials and Methods}

\section{1. $\lambda \mathrm{DNA}$}

$\lambda$ DNA was purchased from New England biolab (NEB). The phage lambda was ligated by adding $1 \mu \mathrm{lof} 500 \mu \mathrm{g} / \mathrm{ml}$ NEB stock to $2 \mu \mathrm{l} 10 \mathrm{X}$ ligase buffer (fermentas), $7 \mu \mathrm{l}$ water, $10 \mu \mathrm{DNA}$, and $1 \mu \mathrm{l}$ T4 DNA ligase (fermentas) which was left at room overnight and stored at $-4^{\circ} \mathrm{C}$. All the different concentrations of $\lambda \mathrm{DNA}$ were used at $1.0 \mu \mathrm{l}$ and $1 \mathrm{X} \mathrm{ABC}$ buffer was used to dilute the concentration of the $\lambda$ DNA.

\subsection{Buffers}

ABC BUFFER- ABC buffer was the standard buffer used in this experimental work and at room temperature. It is made up of $250 \mathrm{mM}$ Tris (PH 7.5), $50 \mathrm{mM} \mathrm{MgCl}_{2}, 250 \mathrm{mM} \mathrm{Kcl}$ and $0.1 \%$ sodium Azide. This was made up of $5 \mathrm{X}$ stock and diluted to $1 \mathrm{X}$, whenever it is used except otherwise stated.

The ABC DTT Buffer (Imaging Buffer) was made up of $200 \mu \mathrm{l} 1 \mathrm{X}$ buffer of $\mathrm{ABC}$ buffer, $700 \mu \mathrm{l}$ water and $100 \mu \mathrm{L}$ of $100 \mathrm{mM}$ DTT.

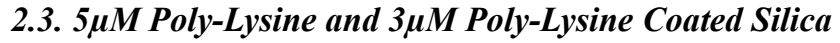 Beads}

$500 \mu \mathrm{l}$ of water was added to $100 \mu \mathrm{l}$ of $5 \mu \mathrm{M}$ beads (silica monospheres (polysciences) which was then vortex and centrifuged at $14 \mathrm{k} \mathrm{rpm}$ for 2 minutes. The water was removed and suspended in $400 \mu \mathrm{l}$ of $350 \mu \mathrm{l} / \mathrm{ml}$ water and stored at $-20^{\circ} \mathrm{C}$.

$500 \mu \mathrm{l}$ water was added to the $100 \mu \mathrm{l}$ of 3 beads of (silica monospheres (polysciences)) which was then vortex and centrifuged at $14 \mathrm{k} \mathrm{rpm}$ for 2 mins. The water was removed and suspended in $400 \mu \mathrm{l}$ of $350 \mu \mathrm{l} / \mathrm{ml}$ water and stored at $20^{\circ} \mathrm{C}$.

\subsection{How Perfusion Tube Was Made}

$1.5 \mu l$ eppendorf tube was drilled at two places above and below each other, using a driller. The driller was first connected to source of electricity and the first hole was drilled at $0.5 \mu$ l of the eppendorf tube while the second hole was drilled at $1.0 \mu \mathrm{l}$. Another hole was also drilled on centre of the eppendorf tube cover which allows tubing to pass through the hole to the bottom of the eppendorf tube. The hole at the cover slide was sealed with glue after the tubing has passed through it to prevent air flow.

\subsection{Flow Cell (Flow Chamber) Construction}

Two holes were drilled on standard glass microscope slide $15 \mathrm{~mm}$ apart. Then two tubing that fit into the holes were cut and fixed through the two holes, it was glued using UV curing adhesive. It was then left near the window for sun shine to dry over night, but if it is not well dried by next day, it is place under UV light box for one hour to dry properly. After that gasket applied to slide were the two tubing are and the cleaned cover slip was fixed to it to create the chamber. The flow cell was recycled each time they used; it was placed in acetone overnight which makes it possible for the slip cover, gasket and tubing to be removed from the slide. Then new tubing, gasket and cleaned cover slip are used to make the flow cell again.

\subsection{How the Syringe Pump and Slip Cover Were Cleaned After Used}

The whole contents in the tubing of the syringe pump were usually pumped out to $1.0 \mu \mathrm{l}$ and methanol was usually withdrawn to $2.5 \mu \mathrm{L}$ and leftover night. The methanol was pumped out before the syringe pump was to be use the next day. The slip cover used is 1.5 (standard) is placed in acetone and sonicator in a sonicator bath for one hour. It is then removed from the sonicator bath and the acetone is poured in the sink. Three beakers of $400 \mathrm{ml}$ were filled with distilled water was and the cover slip was dip three time into each of the beakers and until all the water was removed.

The slip cover used is 1.5 (standard) is placed in acetone and in a sonicator bath for one hour. It is then removed from the sonicator bath and the acetone is poured in the sink. Three beakers of $400 \mathrm{ml}$ were filled with distilled water was and the cover slip was dip three time into each of the beakers and until all the water was removed.

\subsection{How the Beads Were Prepared}

$10 \mu l$ beads $(5 \mu \mathrm{M}$ or $3 \mu \mathrm{M})$ were added to $500 \mu l$ water, which was then spun at $14 \mathrm{k} \mathrm{rpm}$ for 2 minutes. The water was removed and another $500 \mu \mathrm{l}$ of water was added and spun at $14 \mathrm{k} \mathrm{rpm}$ for 
2 minutes. The water was removed and another $100 \mu \mathrm{l}$ of water was added. It was then sonicated at cycle 1, 80\% amplitude, 4 times after 1 second each time. The beads were added immediately to the flow cell using a special tip. The beads density was checked using Nikkon microscope (at the intensity of 6) and $100 \mu 1$ of water was used to further wash the beads then the beads density was check again. It is then stored at $-{ }^{\circ} 4$, if it is not going to be used immediately.

\subsection{Addition of $\lambda \mathrm{DNA}$ to Flow Cell}

$99 \mu \mathrm{l}$ of $1 \mathrm{x}$ buffer was added to $1 \mu \mathrm{l} \lambda$ DNA (NEB), then it put into the into perfusion tube and withdraw to empty with the help of the syringe pump. $320 \mu 1$ of one time ABC buffer was also added to the perfusion tube and Set pump according to protocol 'pump loop' which allow the $\lambda$ DNA to flow back and forth for not less than 20 minutes and not greater than 2 hours. Finally YOYO dye was used to stain the $\lambda$ DNA before imaging.

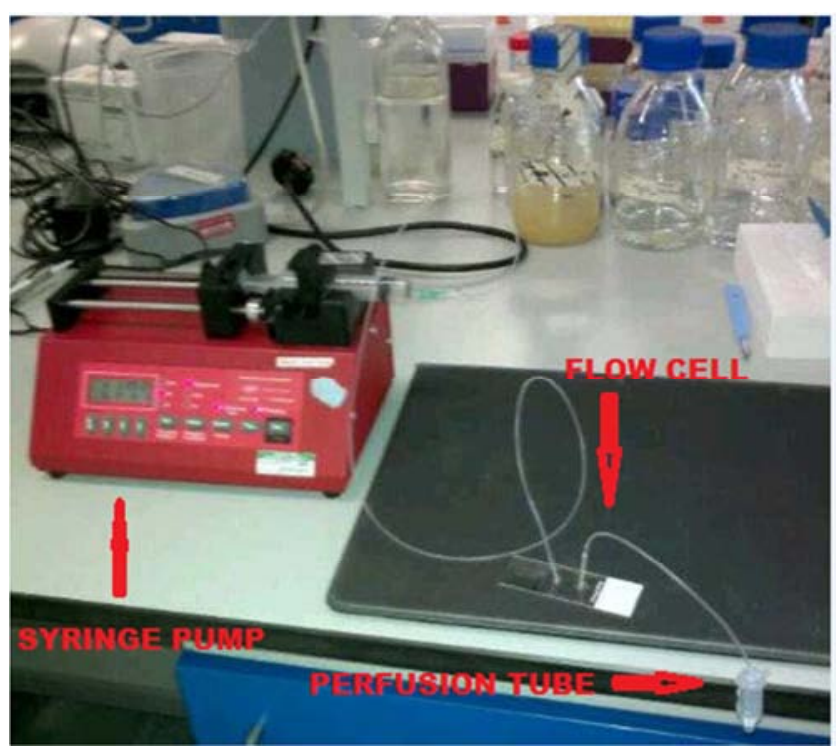

Figure 1. Showing syringe pump, flow cell and perfusion tube set according to protocol, where the syringe dispenses the $\lambda D N A$ in and out of the flow cell to form tightropes.

\subsection{How to Make a $\lambda D N A$ Tightrope}

The flow cell is first filled with water to check if there is any leakage; beads that have been sonicated at 1 cycle by $80 \%$ amplitude were put into the flow cell using a tube with a special tube on it that can fit the tube of the flow cell. After that beads density is check on a light microscope at 6 to view the beads density and if the density is less then it is throw any and another one is made. When the beads density is right, the $1 \mathrm{X} \mathrm{ABC}$ buffer, $\lambda$ DNA and imaging buffer are all added according to the manual's instruction into the perfusion tube. Then the syringe pump, flow cell and perfusion tube are all set fixed together and the syringe pump was set according to protocol to form the tightrope.

$500 \mu 11 \mathrm{xABC}$ buffer was put in an eppendorf tube and then withdrawn into the tubing of syringe pump with careful consideration making sure there is no air bubble. At one end of flow cell tubing was fixed to the tubing of the perfusion tube and the other end of the flow cell the tubing of flow cell was fixed to syringe pump. $500 \mu \mathrm{ABC}$ was put into the perfusion tube and withdrawn to empty; finally the $\lambda$ DNA was put into the perfusion tube and set according to protocol. This was done with careful consideration at any time to avoid air bubble.

The tightropes are constructed using a flow cell (flow through chamber) that allows solutions to pass over beads (poly-L-lysine-coated beads). The solutions are passed through the flow cell using a syringe pump. These beads randomly adhere to the surface of the slip cover when it is passed into the flow cell, but the densities are always checked. $\lambda \mathrm{DNA}$ are then flowed into the flow cell and it suspends the $\lambda$ DNA between the beads to form tightrope. YOYO-1 dye is added to stain the tightrope that is formed during the process, for easy visualization.

\subsection{How the Imaging Was Done}

After the tightrope has been formed in the flow cell and YOYO-1 dye was used to stain the $\lambda \mathrm{DNA}$, atomic force microscopy was used to snap the images in a dark room and computer software (Image J) was used to view all the snapped images.

\section{Results and Discussion}

\subsection{Result for the Beads Size of $5 \mu M$, Concentration of $500.0 \mu \mathrm{g} / \mathrm{ml}$ of $\lambda \mathrm{DNA}$, Velocity of 100, 200, 300, 400, 500 and 600 for the Flow Rate ( $\mathrm{l} / \mathrm{mins})$}

Table 1. Showing numbers tightropes snaped in flow cell at different velocities of (100 to 600). The numbers of multiple strands formed reduces as the velocity increased and increases as the velocity reduces.

\begin{tabular}{lllllll}
\hline \multirow{2}{*}{ Tightropes/Velocities } & $\mathbf{1 0 0}$ & $\mathbf{2 0 0}$ & $\mathbf{3 0 0}$ & $\mathbf{4 0 0}$ & $\mathbf{5 0 0}$ & $\mathbf{6 0 0}$ \\
& Vel & Vel & Vel & Vel & Vel & Vel \\
\hline First image & 6 & 6 & 5 & 4 & 3 & 3 \\
Second image & 6 & 6 & 4 & 4 & 3 & 2 \\
Third image & 5 & 5 & 4 & 3 & 2 & 2 \\
\hline
\end{tabular}
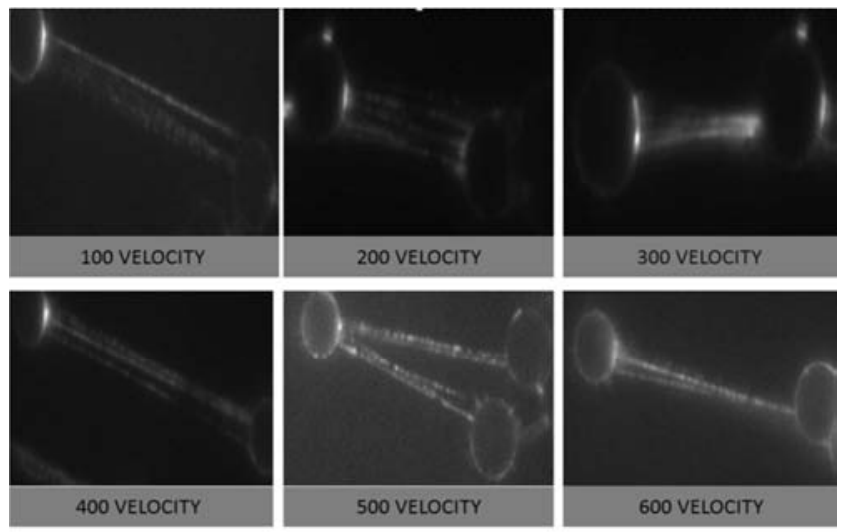

Figure 2. Images of some multiples strand tightropes formed, chosen at random at different velocities. The numbers of multiple strands formed reduced as the velocities were increased and increased at lower velocities.

The result obtained here showed that more multiple strands of tightropes were observed at lower velocity than at higher velocity. At the velocity of $100 \mu \mathrm{l} / \mathrm{mins}$ we had more multiple strands on tight rope than, where DNA on the 
surface of the flow cell was also observed and it took 1 hour for the syringe pump dispense reading to reach $3.000 \mu 1 / \mathrm{mins}$, which means the time increased by 40 minutes compared to the normal protocol. At the velocity of $200 \mu \mathrm{l} / \mathrm{mins}$ there were still multiple strands which were almost the same with $100 \mu \mathrm{l} / \mathrm{mins}$ it took 40 minutes for the syringe pump to dispense reading to reach $3.000 \mu \mathrm{l} / \mathrm{mins}$, which means the time increased by 20 minutes compared to the normal protocol and DNA on the surface of the flow cell was also observed at this velocity. At $300 \mu \mathrm{l} / \mathrm{mins}$ there was no DNA on the surface and the number of multiple DNA tightrope reduced compared to $100 \mu \mathrm{l} / \mathrm{mins}$ and $200 \mu \mathrm{l} / \mathrm{mins}$ it took 20 minutes for the syringe pump to dispense reading to reach $3.000 \mu \mathrm{l} / \mathrm{mins}$, which is the normal time for the normal protocol. At $400 \mu \mathrm{l} / \mathrm{mins}$, there was still multiple strands of tightrope formed and there was no DNA on the surface, where it took 15 minutes for the syringe pump to dispense reading of $3.000 \mu \mathrm{l} / \mathrm{mins}$, which means the time reduced by 5 minutes compared to the normal protocol. At $500 \mu \mathrm{l} / \mathrm{mins}$ the number of multiple strands formed was also reduced compared at lower velocity and there were no DNA on the surface. At 600 also there was no DNA on the surface and the number of multiple strands reduces compared to the ones at lower velocity. It was generally observed here that DNA on the surface was seen at $100 \mu \mathrm{l} / \mathrm{mins}$ and $200 \mu \mathrm{l} / \mathrm{mins}$ velocity and there was no DNA on the surface of the flow cell at the velocity of $300 \mu \mathrm{l} / \mathrm{mins}-600 \mu \mathrm{l} / \mathrm{mins}$.

\subsection{Result for Beads Size of $5 \mu M$, Concentration of 250.0 $\mu \mathrm{g} / \mathrm{ml} \mu \mathrm{l}$ of $\lambda \mathrm{DNA}$, Velocity of 100, 200, 300, 400, 500 and 600 for the Flow Rate ( $\mu l /$ mins)}

Table 2. Showing numbers of multiple strands tightrope formed after imagining the flow cells at various velocities. Higher numbers of multiples strands were seen at lower velocities and less number of multiple strands was seen at lower.

\begin{tabular}{lllllll}
\hline \multirow{2}{*}{ Tightropes/velocities } & $\mathbf{1 0 0}$ & $\mathbf{2 0 0}$ & $\mathbf{3 0 0}$ & $\mathbf{4 0 0}$ & $\mathbf{5 0 0}$ & $\mathbf{6 0 0}$ \\
& Vel & Vel & Vel & Vel & Vel & Vel \\
\hline First image & 5 & 5 & 5 & 4 & 3 & 3 \\
Second image & 4 & 4 & 3 & 3 & 3 & 2 \\
Third image & 3 & 3 & 3 & 3 & 2 & 2 \\
\hline
\end{tabular}
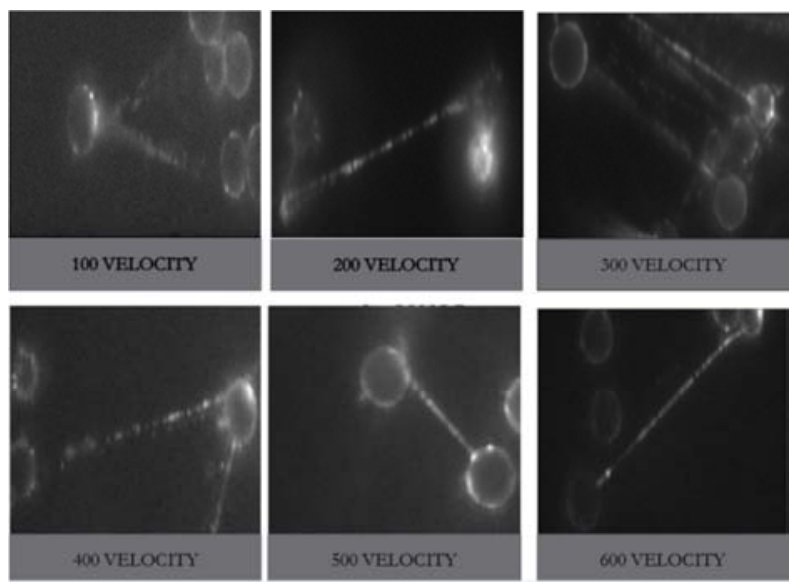

Figure 3. Showing number of the multiple strands formed, where increased in the velocity reduced the number of multiple strands and lower velocity gave higher number of multiples strands.
The result obtained here is similar to the previous condition but less quantity of multiples strands were formed on beads. More quantity of multiple tightropes strands was formed at $100 \mu \mathrm{l} / \mathrm{mins}$ and $200 \mu \mathrm{l} / \mathrm{mins}$ flow rate than at 300, 400500 and 600 velocities. DNA on the surface of the flow cell also observed was observed at 100 and 200 velocities. It took 1 hour for the syringe pump to dispensed reading to reach $3.000 \mu \mathrm{l} / \mathrm{mins}$ at 100 velocity, which means the time increased by 40 minutes compared to the normal protocol. At velocity of $200 \mu \mathrm{l} / \mathrm{mins}$ and it took 40 minutes for the syringe pump to dispensed reading to reach $3.000 \mu 1 / \mathrm{mins}$, which means the time increased by 20 minutes compared to the normal protocol. At $300 \mu \mathrm{l} / \mathrm{mins}$ there was no DNA on the surface and the number of multiple DNA tightrope reduced compared to 100 $\mu \mathrm{l} / \mathrm{mins}$ and $200 \mu \mathrm{l} / \mathrm{mins}$ it took 20 minutes for the syringe pump to dispense reading to reach $3.000 \mu \mathrm{l} / \mathrm{mins}$. At $400 \mu \mathrm{l} / \mathrm{mins}$, there was still multiple strands of tightrope formed and there was no DNA on the surface but slightly less the one at 3000, it took 15 minutes for the syringe pump to dispensed reading of 3.000 $\mu \mathrm{l} /$ mins, which means the time reduced by 5 minutes compared to the normal protocol. At $500 \mu \mathrm{l} / \mathrm{mins}$ the number of multiple strands formed was also reduced compared at lower velocity and there were no DNA on the surface. At 600 also there was no DNA on the surface and the number of multiple strands reduces compared to the ones at lower velocity. It was generally observed here that DNA on the surface was seen at $100 \mu \mathrm{l} / \mathrm{mins}$ and 200 $\mu \mathrm{l} /$ mins velocity and there was no DNA on the surface of the flow cell at the velocity of $300 \mu \mathrm{l} / \mathrm{mins}-600 \mu \mathrm{l} / \mathrm{mins}$.

\subsection{Result for Beads Size of $3 \mu M$, Concentration of 500.0 $\mu \mathrm{g} / \mathrm{ml} \mu \mathrm{l}$ of $\lambda D N A$, Velocity of 100, 200, 300, 400, 500 and 600 for the Flow Rate ( $\mu l / M i n s)$}

Table 3. Showing numbers of multiple strands tightrope formed after imagining, where the numbers of multiple strands reduces with increase in velocity and increased with lower velocity.

\begin{tabular}{lllllll}
\hline \multirow{2}{*}{ Tightropes/velocities } & $\mathbf{1 0 0}$ & $\mathbf{2 0 0}$ & $\mathbf{3 0 0}$ & $\mathbf{4 0 0}$ & $\mathbf{5 0 0}$ & $\mathbf{6 0 0}$ \\
& Vel & Vel & Vel & Vel & Vel & Vel \\
\hline First image & 4 & 4 & 4 & 4 & 3 & 3 \\
Second image & 3 & 3 & 3 & 4 & 2 & 2 \\
Third image & 3 & 3 & 3 & 3 & 2 & 2 \\
\hline
\end{tabular}
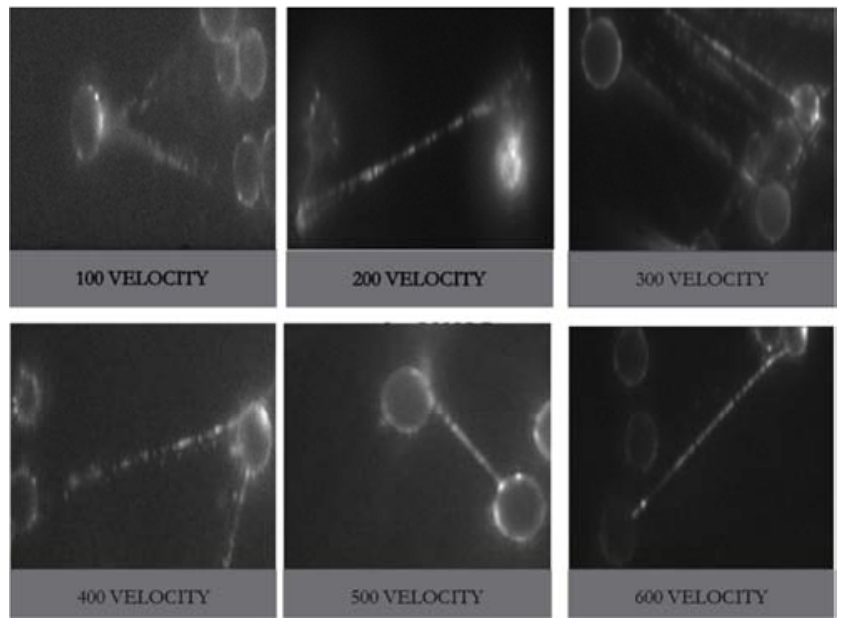

Figure 4. Some of the image snap at different velocity pick at random from the flow cell of each velocity. 
The result obtained here is similar to the previous two conditions, but the reduction in beads size also reduces the numbers of multiple strands that are form two same beads and more quantity of DNA at the velocity of $100 \mu \mathrm{l} / \mathrm{mins}$ and 200 $\mu \mathrm{l} / \mathrm{mins}$ even though there was still multiples strands but there was. At the velocity of $100 \mu \mathrm{l} / \mathrm{mins}$ we had more multiple strands tightrope than at $200 \mu \mathrm{l} / \mathrm{mins}$. At the velocity of 100 $\mu \mathrm{l} / \mathrm{mins}$ it took 1 hour for the syringe pump to dispense reading to reach $3.000 \mu \mathrm{l} / \mathrm{mins}$. At the velocity of $200 \mu \mathrm{l} / \mathrm{mins}$ there. At $300 \mu \mathrm{l} / \mathrm{mins}$ there was no DNA on the surface and the number of multiple DNA tightropes increased compared to 100 $\mu \mathrm{l} / \mathrm{mins}$ and $200 \mu \mathrm{l} / \mathrm{mins}$. At $400 \mu \mathrm{l} / \mathrm{mins}$, there was still multiple strands of tightrope formed and there was no DNA on the surface. At $500 \mu \mathrm{l} / \mathrm{mins}$ the number of multiple strands formed was also reduced compared at lower velocity and there were no DNA on the surface and there was no DNA on the surface. At 600 also there was no DNA on the surface and the number of multiple strands reduces compared to the ones at lower velocity. It was generally observed here that DNA on the surface was seen at $100 \mu \mathrm{l} / \mathrm{mins}$ and $200 \mu \mathrm{l} / \mathrm{mins}$ velocity and there was no DNA on the surface of the flow cell at the velocity of $300 \mu \mathrm{l} / \mathrm{mins}-600 \mu \mathrm{l} / \mathrm{mins}$. Higher numbers of multiples strands was seen at $300 \mu \mathrm{l} / \mathrm{mins}$ and $400 \mu \mathrm{l} / \mathrm{mins}$.

\subsection{Result for the Beads size of $3 \mu \mathrm{M}$, Concentration of $375.0 \mu \mathrm{g} / \mathrm{ml} \mu \mathrm{L}$ of $\lambda \mathrm{DNA}$, Velocity of 100, 200, 300, 400, 500 and 600 for the Flow Rate ( $\mu$ L/Mins)}

Table 4. Showing numbers of single and multiple tightropes formed at different velocities, where the numbers of multiple strands reduces with increase in velocity.

\begin{tabular}{lllllll}
\hline \multirow{2}{*}{ Tightropes/velocities } & $\mathbf{1 0 0}$ & $\mathbf{2 0 0}$ & $\mathbf{3 0 0}$ & $\mathbf{4 0 0}$ & $\mathbf{5 0 0}$ & $\mathbf{6 0 0}$ \\
& Vel & Vel & Vel & Vel & Vel & Vel \\
\hline First image & 1 & 1 & 3 & 2 & 1 & 1 \\
Second image & 1 & 1 & 2 & 2 & 1 & 1 \\
Third image & 0 & 1 & 2 & 2 & 1 & 0 \\
\hline
\end{tabular}
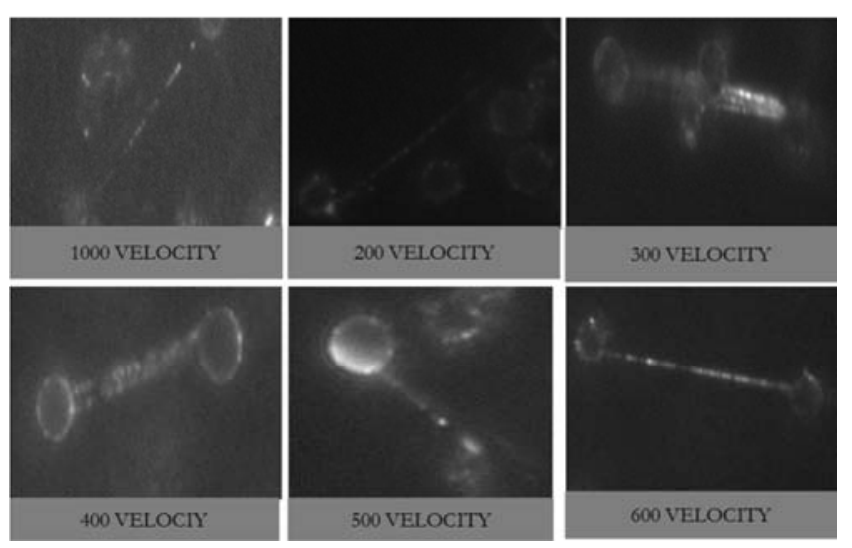

Figure 5. Showing numbers multiple strands, there were no multiple strands at the velocity of 100, 200 and 600 .

The result obtained here is different from all the previous conditions where there was no multiple strands on $100 \mu \mathrm{l} / \mathrm{mins}$, $200 \mu \mathrm{l} / \mathrm{mins}, 500 \mu \mathrm{l} / \mathrm{mins}$ and $600 \mu \mathrm{l} / \mathrm{mins}$ velocity. DNA on the surface surface of the floe cell was still observed at $100 \mu \mathrm{l} / \mathrm{mins}$ and $200 \mu \mathrm{l} /$ mins velocity but $100 \mu \mathrm{l} /$ mins velocity had more DNA on the surface. Multiples strands was observed at $300 \mu \mathrm{l} / \mathrm{mins}$ and
$400 \mu \mathrm{l} / \mathrm{mins}$ but $300 \mu \mathrm{l} / \mathrm{mins}$ had more multiple strands.

\subsection{Result for the Beads Size of $3 \mu M$, Concentration of $250.0 \mu \mathrm{g} / \mathrm{ml} \mu \mathrm{l}$ of $\lambda \mathrm{DNA}$, Velocity of 100, 200, 300, 400, 500 and 600 for the Flow Rate ( $\mu$ l/Mins)}

Table 5. Showing numbers of single and multiple tightropes formed at different velocities, where the numbers of multiple strands reduces with increase in velocity.

\begin{tabular}{lllllll}
\hline \multirow{2}{*}{ Tightropes/velocities } & $\mathbf{1 0 0}$ & $\mathbf{2 0 0}$ & $\mathbf{3 0 0}$ & $\mathbf{4 0 0}$ & $\mathbf{5 0 0}$ & $\mathbf{6 0 0}$ \\
& Vel & Vel & Vel & Vel & Vel & Vel \\
\hline First image & 1 & 1 & 2 & 2 & 1 & 1 \\
Second image & 0 & 1 & 2 & 1 & 1 & 0 \\
Third image & 0 & 0 & 1 & 1 & 1 & 0 \\
\hline
\end{tabular}
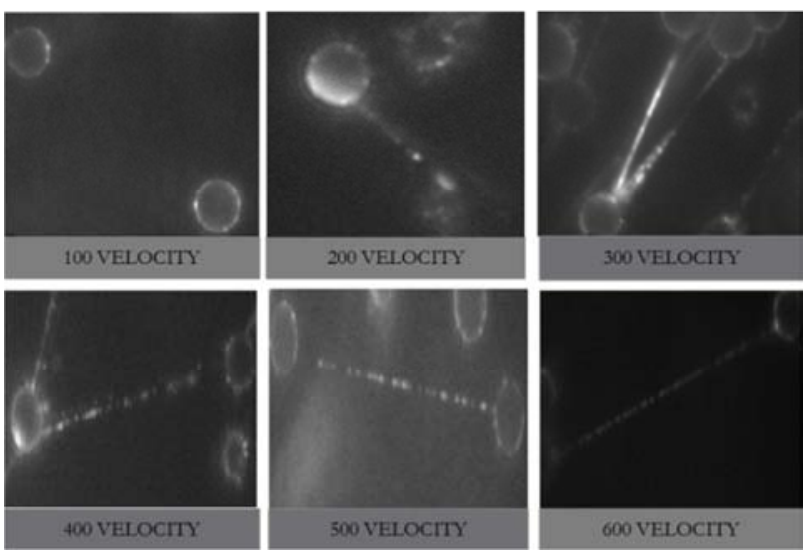

Figure 6. Some of the multiples strand tightropes from different velocities picked at random. Where multiple strands as seen at 300 and 400 velocity.

The result obtained is similar to the previous condition but few tightrope where formed her in general compared to the previous one. DNA on the surface was observed at $100 \mu \mathrm{l} / \mathrm{mins}$ and 200 $\mu \mathrm{l} / \mathrm{mins}$ velocity of flow rate, but $100 \mu \mathrm{l} / \mathrm{mins}$ had more DNA on the surface. 100 velocity did not have many tightrope only one, most of the DNA was seen at the surface of the flow cell. 200 $\mu \mathrm{l} /$ mins velocity had more tightropes than $100 \mu \mathrm{l} / \mathrm{mins}$ and it still had DNA on the surface of the tightrope. At $300 \mu \mathrm{l} / \mathrm{mins}$ and 400 $\mu \mathrm{l} /$ mins there where more DNA tightrope and some multiples tightrope but the still less compared to the previous conditions. At $500 \mu \mathrm{l} / \mathrm{mins}$ and $600 \mu \mathrm{l} / \mathrm{mins}$, there was also no DNA on the surface and no multiples strands of tightrope. Generally the numbers or amount of tight ropes formed at this condition was less generally compared to all the conditions.

\subsection{Result for the Beads Size of $3 \mu M$, Concentration of $375.0 \mu \mathrm{g} / \mathrm{ml}$ of $\lambda D N A$, Velocity of $100 \mu \mathrm{l} / \mathrm{Mins}, 200$ $\mu \mathrm{l} / \mathrm{Mins}, 300 \mu \mathrm{l} / \mathrm{Mins}, 400 \mu \mathrm{l} / \mathrm{Mins}, 500 \mu \mathrm{l} / \mathrm{Mins}$ and $600 \mu \mathrm{l} / \mathrm{Mins}$ for the Flow Rate Where all the Velocities Were Performed for 15 Minutes}

Table 6. Showing numbers of multiple strands and single strand image tightrope formed after imagining, where the numbers of multiple strands reduces with increase in velocity.

\begin{tabular}{lllllll}
\hline \multirow{2}{*}{ Tightropes/velocities } & $\mathbf{1 0 0}$ & $\mathbf{2 0 0}$ & $\mathbf{3 0 0}$ & $\mathbf{4 0 0}$ & $\mathbf{5 0 0}$ & $\mathbf{6 0 0}$ \\
& Vel & Vel & Vel & Vel & Vel & Vel \\
\hline First image & 1 & 1 & 1 & 1 & 1 & 1 \\
Second image & 1 & 1 & 1 & 1 & 1 & 1 \\
Third image & 0 & 1 & 1 & 1 & 1 & 0 \\
\hline
\end{tabular}



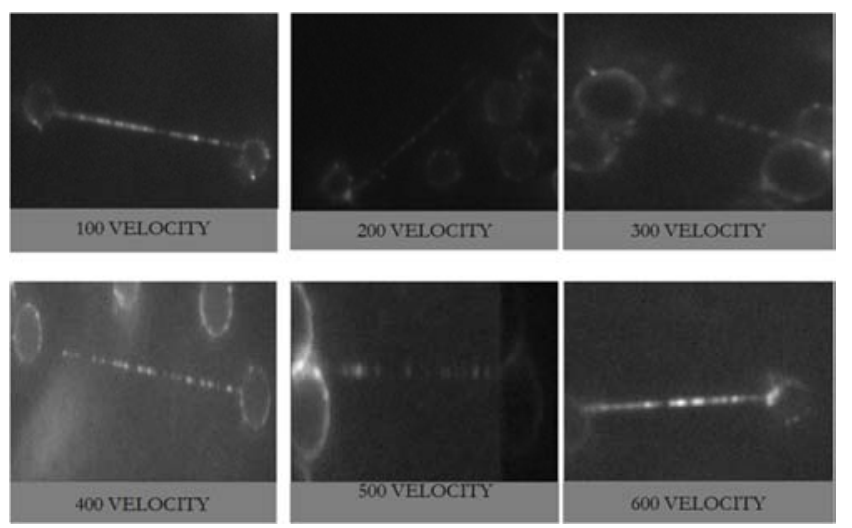

Figure 7. Showing the numbers of single stranded picked at random. Where all the velocities has single strands of the $\lambda D N A$.

\section{Conclusion}

To overcome the problems of multiple tightropes, different conditions such as bead size $(5 \mu \mathrm{M}$ and $3 \mu \mathrm{M})$, concentration of $\lambda$ DNA $(500.0 \mu \mathrm{g} / \mathrm{ml}, 375.0 \mu \mathrm{g} / \mathrm{ml}$ and $250.0 \mu \mathrm{g} / \mathrm{ml})$, velocities of the syringe pump flow rate $(100,200,300,400$, 500 and 600) and time were used for the optimization. This study tried to get the lowest velocity that had the highest numbers of single stranded tightrope amongst all the conditions (bead size, concentration of $\lambda \mathrm{DNA}$, velocity of flow rate and time) because at high velocity it can create tensions in the $\lambda$ DNA. The normal protocol for making these $\lambda$ DNA tightropes used beads size of $5 \mu \mathrm{M}$, velocity of 300 $\mu \mathrm{l} / \mathrm{mins}$ for the flow rate, concentration of $500.0 \mu \mathrm{g} / \mathrm{ml}$ and dispenses reading of not less than $3.0 \mu \mathrm{l} / \mathrm{mins}$, but in this work most of the conditions were optimized to get single stranded tightrope. Making the flow cell was sometimes challenging because once an air get inside the flow cell a new flow cell has to be made because air usually move the beads to one side of the flow cell.

The beads size of $3 \mu \mathrm{M}$, concentration of $375.0 \mu \mathrm{g} / \mathrm{ml} \mu \mathrm{l}$ and velocity of $300 \mu \mathrm{l} / \mathrm{mins}$ for 15 minutes gave the highest number of single stranded $\lambda$ DNA tightropes compare to all the conditions used, with no multiple strands of $\lambda \mathrm{DNA}$. This became the best result because it has high quantity of $\lambda$ DNA tightrope, that does not have multiple strands and at a lower velocity which can't create tension in the beads. The velocity is the same with the normal protocol but the bead size was changed from $5 \mu \mathrm{M}$ to $3 \mu \mathrm{M}$ and the concentration from $500.0 \mu \mathrm{g} / \mathrm{ml}$ to $375.0 \mu \mathrm{g} / \mathrm{ml}$. Changing the beads size from 5 $\mu \mathrm{M}$ reduces the surface area of the beads which prevented it from forming multiple strands on the beads. Reducing the concentration of the $\lambda$ DNA from $500.0 \mu \mathrm{g} / \mathrm{ml}$ to $375.0 \mu \mathrm{g} / \mathrm{ml}$ reduce the amount of DNA to be use, thereby reducing the amount of multiple strands $\lambda$ DNA tightropes that was formed on the beads. The time was reduced from 20 minutes to 15 minutes because longer time was responsible for multiple $\lambda$ DNA tightropes to form on the beads. The amount of YOYO-1 dye used was increased from $15 \mu \mathrm{l}$ to $20 \mu \mathrm{l}$ to give clearer images of the $\lambda \mathrm{DNA}$ tightrope.

The work reported by [3] that DNA tightrope is powerful for image location which is in agreement with the research reported here. DNA tightropes makes manipulations of DNA easier to be view while carry molecular studies such as DNA repairs, cancer studies, studying some specific sites and DNA-protein interaction. DNA tightropes provide an environment which allows DNA to be viewed holistically by powerful visualization tools.

\section{References}

[1] Kad N. M., Wang H., Kennedy G. G., Warshaw D. M., and Van Houten B., (2010). Collaborative dynamic DNA scanning by nucleotide excision repair proteins investigated by singlemolecule imaging of quantum-dot-labeled proteins. Molecular Cell, 37: 702-713.

[2] Gorman J., and Greene E. C. (2008). Vsisualizing onedimensional diffusion of proteins along DNA. Nat. Struct. Mol. Biol. 15, 768-774.

[3] Cornish P. V., and Ha T., (2007). A survey of single-molecule techniques in chemical biology. ACS Chemical Biology, 2: 53-61.

[4] Wang J., Barnett J. T., Pollard M. R., Kad N. M. (2016). Integrating Optical Tweezers, DNA Tightropes, and SingleMolecule Fluorescence Imaging: Pitfalls and Traps. Methods in Enzymology. 1-22.

[5] Pan H., Bilinovich M. S., Kaur P., Riehn R., Wang H. and Williams C. D., (2017). CpG and methylation-dependent DNA binding and dynamics of the methylcytosine binding domain 2 protein at the single-molecule level. Nucleic Acids Research. $1-14$.

[6] Wu D., Kaur P., Li M. Z., Bradford C. K., Wang H., and Erie A. D. (2016) Visualizing the Path of DNA through Proteins Using DREEM Imaging. Molecular Cell 61, 315-323.

[7] Hughes D. C., Wang H, Ghodke H., Simons M., Towheed A., Peng Y., Houten V. and Kad M. N. (2013) Real-time single-molecule imaging reveals a direct interaction between UvrC and UvrB on DNA tightropes. Nucleic Acids Research; 1-12.

[8] Bustamante C., Bryant Z., and Smith S. B., (2003). Ten years of tension: Single-molecule DNA mechanics. Nature, 421: 423-427.

[9] Ngwu NW, Effa EB, Ftepti BJ, Gali AI, Useh MU, Samuel CJ. (2016). Biochemical Studies of Ocimum sanctum and Olax subscorpioidea leaf extracts. British Journal of Pharmaceutical Research. 12 (4): 1-9.

[10] Walter N. G., Huang C. Y., Manzo A. J., and Sobhy M. A., (2008). Do-it-yourself guide: How to use the modern singlemolecule toolkit. Nature Methods, 5: 475-489.

[11] Joo C., Balci H., Ishitsuka Y., Buranachai C., and Ha T., (2008). Advances in single-molecule fluorescence methods for molecular biology. Annual Review of Biochemistry, 77: 5176.

[12] Simons M., Pollard R. M., Hughes D. C., Ward D. A., Houten V. B., Towrie M., Botchway W. S., Parker W. A. and Kad M. N. (2015) Directly interrogating single quantum dot labelled UvrA2 molecules on DNA tightropes using an optically trapped nanoprobe. Scientific Reports. 5: 18486. 
[13] Ashkin A., Dziedzic J. M., and Yamane T., (1987). Optical trapping and manipulation of single cells using infrared-laser beams. Nature, 330: 769-771.

[14] Springall L., Hughes D. C., Simons M., Azinas S., Houten V. B. and Kad M. N. (2017). Recruitment of UvrBC complexes to UV-induced damage in the absence of UvrA increases cell survival. Nucleic Acids Research: 1-10.

[15] Von Hippel P. H., and Berg O. G., (1989) Facilitated target location in biological systems. Journal of Biological Chemistry, 264: 675-678.

[16] Shimamoto N., (1999). One-dimensional diffusion of proteins along DNA. Its biological and chemical significance revealed by single molecule measurements. Journal of Biological Chemistry, 274: 15293-15296.

[17] Halford S. E., and Marko J. F., (2004). How do site-specific binding proteins find their targets? Nucleic Acids Research, 32: $3040-3052$.

[18] Spies M., Bianco P. R., Dillingham M. S., Handa N., Baskin R. J., and Kowalczykowski S. C., (2003). A molecular throttle: The recombination hotspot, $\chi$, controls DNA translocation by the RecBCD helicase. Cell, 114: 647-654.
[19] Kim J. H., and Larson R. G., (2007). Single-molecule analysis of 1D diffusion and transcription elongation of T7 RNA polymerase along individual stretched DNA molecules. Nucleic Acids Research, 11: 3848-3858.

[20] Kabata H., Kurosawa O., Arai I., Washizu M., Margarson S. A., Glass R. E. and Shimamoto, N. (1993). Visualization of single molecules of RNA polymerase sliding along DNA. Science, 262: 1561-1563.

[21] Greene E. C., and Mizuuchi K., (2002). Direct observation of single $\mathrm{MuB}$ polymers: evidence for a DNA-dependent conformational change for generating an active target complex. Molecular Cell, 9: 1079-1089.

[22] Van Oijen A. M., Blainey P. C., Crampton D. J., Richardson C. C., Ellenberger T., and Xie X. S., (2003). Single-molecule kinetics of lambda exonuclease reveal base dependence and dynamic disorder. Science, 301: 1235-1238.

[23] Graneli A., Yeykal C. C., Prasad T. K., and Greene E. C., (2006). Organized arrays of individual DNA molecules tethered to supported lipid bilayers. Langmuir, 22: 292-299. 